Review

\title{
The Role of Galectins in Tumor Progression, Treatment and Prognosis of Gynecological Cancers
}

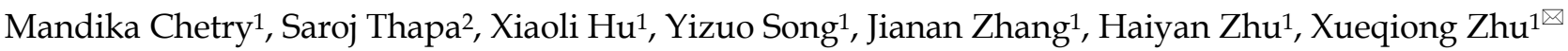 \\ 1. Department of obstetrics and Gynecology, the Second Affiliated Hospital of Wenzhou Medical University. Wenzhou 325027, China \\ 2. MD, Department of Internal Medicine, the Second Affiliated Hospital of Wenzhou Medical University. Wenzhou 325027, China \\ $\triangle$ Corresponding author: Prof. Dr. Xueqiong Zhu, email:zjwzzxq@163.com, phone number: 08613906640759. ORCID: 0000-0002-8389-928X \\ (c) Ivyspring International Publisher. This is an open access article distributed under the terms of the Creative Commons Attribution (CC BY-NC) license \\ (https://creativecommons.org/licenses/by-nc/4.0/). See http://ivyspring.com/terms for full terms and conditions.
}

Received: 2017.11.02; Accepted: 2018.09.13; Published: 2018.11.25

\begin{abstract}
Galectins are the member of soluble proteins that bind with $\beta$-galactoside containing glycans. These proteins have been considered to be associated in various important events such as different types of cancers. It has been found that galectins could contribute to neoplastic transformation or regulate cell growth, cell apoptosis, and immune cells, causing tumor invasion, progression, metastasis and angiogenesis. Somehow, galectins are also found to exert a protective effect on cancer in a tissue-dependent way. These glycans binding proteins have been shown to be involved in the regulation of different tumor suppressor genes and oncogenes with their possible roles in human cancers. Objective of the current review is to summarize the role of galectin-1, $-3-7$, and -9 in tumorigenesis of gynecological cancers. Galectin protein may be a potential therapeutic target in gynecological malignancies due to reported radio- and chemo- sensitivities, immunotherapeutic, anti-angiogenic and anti-proliferative activities. This review considers the evidence for the future research that how galectins may be important in the progression and treatment of gynecological cancers along with its potent use as a novel prognostic marker.
\end{abstract}

Key words: galectins, gynecological cancers, cervical cancer, ovarian cancer, endometrial cancer

\section{Introduction}

Galectins are the S - type of lectins highly expressing in macrophage of immune system. These proteins are well known to bind with $\beta$-galactoside glycoprotein residues with the carbohydrate recognition domain (CRD). There are 15 different subtypes in this family that have been identified in a wide variety of human cells and tissues.

Elevated level of several galectin members in cancer patients modifies immune surveillance thereby contributing to tumor metastasis and progression ${ }^{1}$. Various crystal structures of galectins have been elucidated, representing that these proteins hold at least a single preserved domain of approximately 130 amino acids selected as the CRD that is subjected for their carbohydrate-binding functions ${ }^{2}$. Different galectins share a conserved CRD, which could be unique or repeated ${ }^{3}$. Based on the structures of galecins, they have been divided into three subgroups: the prototype sub-family (galectin- $-1,-2,-5$, $-7,-10,-11,-13,-14$ and -15$)$ which has unique CRD, the tandem-repeat sub-family (galectin-4, $-6,-8,-9$ and -12) which contains double non-identical CRDs with short peptide sequence and the chimera-type (galectin-3) which is comprised of an unusual proline, extended $\mathrm{N}$-terminal tail, tyrosine and abundant glycine domain connected with CRD ${ }^{4}$.

Galectins are present inside the cytosol, closed to the cellular membrane, or in the extracellular space, showing that they are probably released via nonclassical secretory pathways, which needs to be elaborated in the future. The galectin proteins located within the cytoplasm and nucleus sections have several intracellular properties like transition of signaling pathways, controlling of RNA splicing, intracellular regulation of apoptotic signaling, endocytic machinery and trafficking ${ }^{5}$. Galectins are prone to homodimerize and oligomerize, which is a vital feature of them that increases the glycan binding valency and interaction of galectins with multiple glycoconjugates 6,7 . 
A. Three types of galectin structure

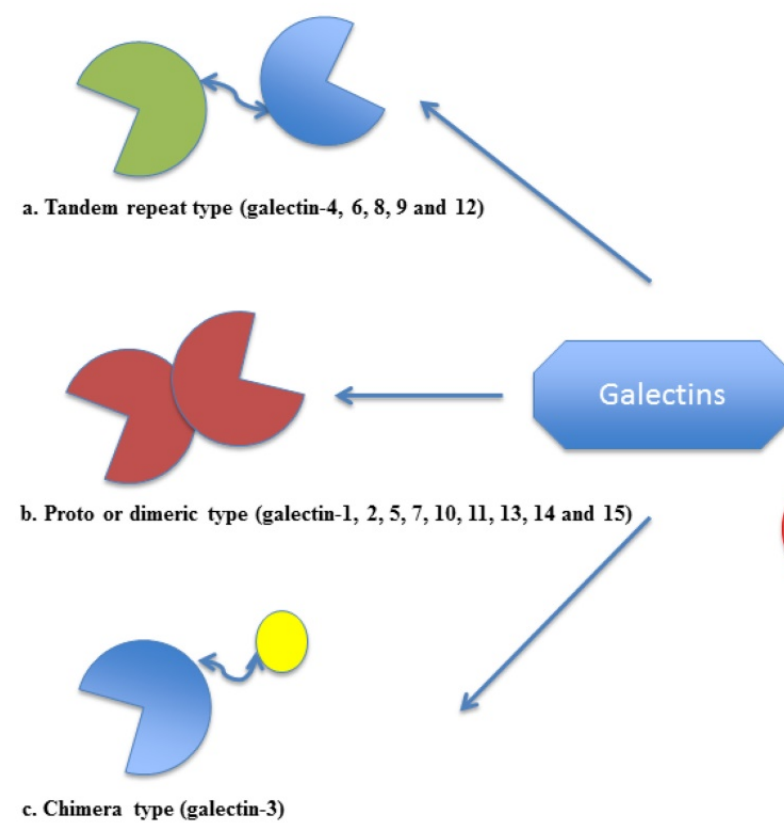

B. Intracellular functions
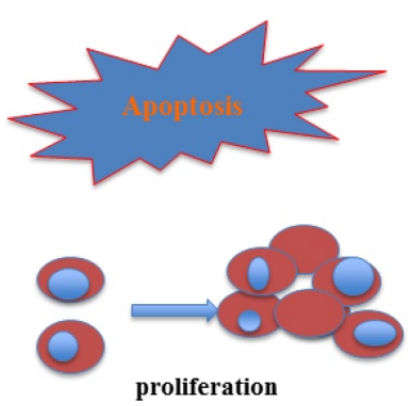

O

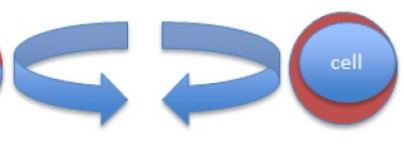

interaction

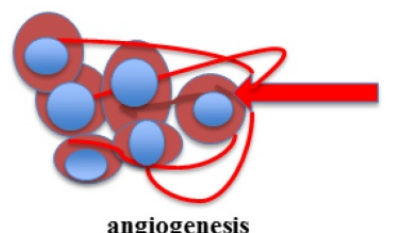

Fig. 1 (A) Galectin family and structure (B) The intracellular functions of galectins. (a) The tandem-repeat sub-family, which contains two non-identical CRDs with short peptide sequence, (b) the prototype subfamily, which has single CRD and (c) the chimera-type, which was composed of an unusual proline, extended $\mathrm{N}$-terminal tail, tyrosine and abundant glycine domain connected to the CRD.

Multiple studies have reported that the concentration of the galectins and their subgroups were significantly increased in several human cancers such as: gastric, colorectal, lung, prostate, bladder, head-neck cancers and melanoma ${ }^{8-12}$. The frequently reported galectin subtypes so far in gynecological cancers are galectin-1, -3, -7 and -9 . Galectin- 1 is a homodimeric protein composed of $14.5 \mathrm{kDa}$ subunits 13 that binds cells outside to matrix and other cells, thus promoting cell proliferation and motility ${ }^{14}$. It has been revealed that this protein is involved in multivalent components that cluster cell surface glycoproteins ${ }^{15}$, angiogenesis ${ }^{16}$, and cross-link receptors ${ }^{17}$; promote $\mathrm{T}$ cell apoptosis 18 , inhibit various aspects of $\mathrm{T}$ cell effector functions ${ }^{19}$ and form lattices in larger aggregates ${ }^{20}$. Galectin-3 is expressed by macrophages, activated $\mathrm{T}$ cells, fibroblasts, epithelial and tumor cells, and eosinophils, mediating antiapoptotic signaling ${ }^{21}$. The functions of galectin-3 are associated with diverse types of acute and chronic inflammatory responses (microbial infection, asthma, liver injury and fibrosis) 22, oxidative stress, heart failure ${ }^{23}$, angiogenesis ${ }^{24}$ and cancer metastasis ${ }^{25}$. In addition, galectin-7 is a $15-\mathrm{kDa}$ proto-type protein, whose expression is mostly restricted to squamous epithelial, epidermal and stratified epithelial cells 26,27 . This protein contributes to either neoplastic transformation or tumor progression via regulation of cell development, cell migration, angiogenesis, apoptosis and radiation response or a preventive outcome in cancer 28 . Galectin-9 belongs to the tandem-repeat subfamily of galectins, which contain two different CRD domains separated by a flexible linker ${ }^{29}$. Several researches have confirmed that galectin- 9 might be involved in the formation and metastasis of human tumors such as breast cancer, and played a crucial role in the development and prognosis of malignancies 30 (Fig. 1).

Recently, numerous effects have been made to investigate the role of galectins in specific gynecological malignancies including cervical, ovarian and endometrial cancers. Thus, this article will focus on three issues listed as below: (1) altered galectin-1, -3 , -7 and -9 expressions and the risk of gynecologic cancers progression; (2) the capability of these galectins as a promising target for treatment in gynecological malignancies; (3) galectins may be important as the novel potential prognostic marker for gynecological cancers.

\section{The role of galectin-1 in gynecological cancers}

Cervical cancer

Expression and role of galectin- 1 in cervical cancer

Several experimental model systems have been conducted to explore the expression and the role of 
galectin-1 in cervical cancer. For example, one group suggested that galectin-1 expression was higher in cervical cancer, and may thus favored different biological behaviors ${ }^{31}$. Furthermore, some immunohistochemical studies detected increased galectin-1 expression in intracellular tumor (nuclei and cytoplasm) portion, peritumoral stromal portion 32,33 and extracellular stromal portion ${ }^{31,34}$, or in fibrocytes and fibroblasts in the stroma ${ }^{35}$ of cervical cancer. Conversely, these studies had shown negative or absent expression of galecin-1 in normal cervical tissue samples. Additional evidence revealed that knock-down of galectin-1 with siRNA could limit the proliferative and invasive capability of cervical cancer cells in vitro. Moreover, immunohistochemistry (IHC) further illustrated that up-regulation of galectin-1 was linked with lymph node metastasis and increased intensity of tumor invasion in cervical cancer. Consistently, Kohrenhagen et al. showed that positive galectin-1 immunohistochemical staining intensity in cervical stromal cells was higher according to the pathological grade, in particular, significant number of these cells with highly expressed galectin-1 were most frequently noticed in high grade squamous intraepithelial lesions (HGSIL, 17/20) and invasive squamous cell carcinoma (ISCC, 19/20) 35. Nonetheless, epithelial cells were found with negative galectin-1 expression. On the contrary, in low grade squamous intraepithelial lesions (LGSIL), the galectin1 expression had low intensity $(10 / 20)$ and majority of the normal cervical tissues $(12 / 20)$ had no galectin-1 expression. Thus, it was revealed that the expression of galectin-1 was markedly increased in ISCC compared with normal cervical tissues and LGSIL. When four of distinct histopathologic level of cervical samples were compared with the positive staining of high galectin-1, the results displayed that the number of positive samples were gradually increased according to the pathological grade i.e. from normal cervical tissues to LGSIL, HGSIL and ISCC (normal cervical tissue <LGSIL < HGSIL <ISCC), indicating that overexpression of galectin-1 in cervical cancer was associated with the progression of cervical neoplasia.

\section{Therapeutic potential of galectin-1 in cervical cancer}

In our previous study, we revealed that the level of galectin-1 in stage IB-IIA cervical cancer specimens was significantly decreased after neoadjuvant intra-arterial chemotherapy (uterine artery injection of cisplatin $60 \mathrm{mg} / \mathrm{m}^{2}+5$-flurouracil $750 \mathrm{mg} / \mathrm{m}^{2}+$ mitomycin $C 8 \mathrm{mg} / \mathrm{m}^{2}$ ) therapy, using western blot results ${ }^{33}$. When compared to galectin-1 knock-down cells transfected with scrambled RNA or galectin-1 siRNA, Hela cells with overexpression of galectin-1 transfected with green fluorescent protein (GFP) vector and galectin-1 cDNA had significantly higher surviving fractions after being treated with $0,2,4,6$ or 8 Gy of irradiation $48 \mathrm{~h}{ }^{36}$. In addition, the clonogenic viability of HeLa cells was increased by high expression of galectin-1, while its knock-down did not change clonogenic viability in C33A (weak galectin-1 expression) cells. The result showed that overexpression of galectin-1 could inhibit radiation mediated cell death in these cells. Furthermore, the evidence speculated that neither galectin-1 knock-down decreased the clonogenic viability of HeLa cells with H-Ras knock-down nor overexpression increased viability of C33A cells with $\mathrm{H}$-Ras knock-down. However, clonogenic viability of HeLa cells was significantly lowered with galectin-1 knock-down or transfection with constitutively active $\mathrm{H}$-Ras at greater dose, protecting HeLa cells from radiation-mediated cell death. Galectin-1 knock-down with galectin-1 shRNA also inhibited the impact of phosphorylated Raf-1 and signal regulated kinase function following irradiation, whereas in C33A cells, these effects were increased by the galectin-1 overexpression. The study has also exhibited that galectin-1 knock-down in HeLa cells following 4 and $24 \mathrm{~h}$ irradiation led to severe DNA damage and overexpression decreased the damage in C33A cells. After 4-h irradiation, down-regulation of galectin-1 promoted the expression of $\gamma-\mathrm{H} 2 \mathrm{AX}$ (DNA damage marker) than in scrambled RNA transfected cells, and overexpression of galectin- 1 decreased the $\mathrm{\gamma}-\mathrm{H} 2 \mathrm{AX}$ expression in C33A cells. Thus, the study indicated that galectin-1 mediated the radio-resistance in cervical cancer through H-Ras dependent pathways and was involved in DNA damage repair, therefore aiming on galectin-1 may be regarded as a radio-sensitizing therapy for cervical cancer.

Tumor infiltrating lymphocytes ( $\gamma \delta T I L s)$ was broadly applied in clinical research due to the adoptive immunotherapy function, inhibiting early stages of tumor development and limiting the progression of cancer ${ }^{37}$. Li et al. demonstrated that galectin-1 significantly enhanced the cytotoxicity of

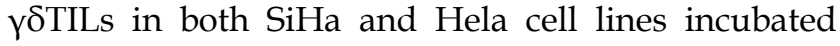
with the inhibitors of galectin-1 (either lactose or galectin-1 antibody), compared with the control (medium only) and isotype IgG of anti-galectin- $1{ }^{38}$. The co-treatment of $\gamma \delta$ TILs and galectin- 1 antibody in cervical cancer xenografted severe combined immunodeficient mice could apparently decrease tumor growth in comparison with control (without treatment) after intra-tumoral injection every 3 days and 10 times in total. Intriguingly, galectin- 1 antibody used alone also inhibited tumor proliferation in vivo after 30-days implantation of SiHa cells. In addition, 
combined administration of these two agents was more efficient than one of them as monotherapy. Hence, galectin-1 antibody can act as a reliable immunotherapy for cervical cancer patients.

In our recently published study, we observed that cervical cancer tissue both in tumor cell and stromal cell consistently showed high galectin-1 expression before treating with cisplatin-based chemotherapy, whereas the expression was decreased after chemotherapy ${ }^{39}$. It was determined that chemotherapy down-regulated the expression of galectin-1 in both cells (stromal and tumor) of cervical cancer patients, suggesting that galectin-1 protein was responsible for the cisplatin-based chemo-sensitivity. In addition, galectin-1 expression in stromal cells was significantly lower in the chemotherapy responding group than that in non-responding group, which highlighted that overexpression of galectin-1 in stromal cells was more resistant to cisplatin-based neoadjuvant therapy. Thus, galectin-1 expression may act as a potential predictive biomarker to cisplatin-based neoadjuvant therapy response in cervical cancer patients.

\section{Role of galectin-1 in the prognosis of cervical cancer}

It had been anticipated that changes in the levels of galectin-1 might determine the prognosis of cervical cancer. Compared with the clinicopathological findings, Kim et al. exhibited that galectin-1 was not associated with progression free survival (PFS) in patients with cervical cancer ${ }^{32}$. The 5-year PFS for patients with low galectin-1 expression was $84 \%$, whereas for high galectin-1 expression was $73.2 \%$. In another study, the receiver operating characteristics curve analysis indicated a better predictive ability of galectin-1 expression in specimens of cervical squamous cell carcinoma (SCC, stage I-II, after radiation therapy) for local recurrence (LR) and cancer specific survival (CSS) than stromal expression ${ }^{34}$. However, the expression of galectin- 1 in the cancer cells and in the stroma cells did not predict distant metastasis. The univariate study displayed that galectin-1 expression in SCC was associated with both LR and CSS. The 10-year LR rates were 7.5\% (no expression), $18.7 \%$ (weak expression) and 34.5\% (moderate to strong expression) in tumor cells with galectin-1 expression, respectively. The corresponding 10-year CSS rates were $90 \%, 81.3 \%$ and $67.8 \%$ respectively, while corresponding distant metastasis rates were $11.3 \%, 10.7 \%$ and $15.8 \%$ respectively. But stromal galectin-1 expression in cervical cancer was not dramatically associated with LR, CSS, or distant metastasis. Subsequently, Punt et al. 31 revealed similar results with Kaplan Meier survival curve and found that strong expression of galectin- 1 in tumor cells was significantly correlated with poor disease-free and disease-specific survival in patients with squamous cervical cancer.

\section{Ovarian cancer}

\section{Expression and role of galectin- 1 in ovarian cancer}

Overexpression of galectin-1 was predominantly noted in peritumoral stroma samples and cytoplasm of epithelial ovarian cancer (EOC) cells, whereas it was not detected in all the analyzed normal ovarian tissues $40-43$. In histological subtypes, cytoplasmic galectin-1 staining in cancer cells was significantly higher in serous, clear cells and endometrioid types, whereas low galectin-1 staining was present in mucinous type ${ }^{43}$. Moreover, the staining intensity illustrated that expression of galectin-1 in the peritumoral stroma was significantly associated with advanced-stage EOC, serous histology and a residual tumor $\geq 1 \mathrm{~cm}$ after primary debulking surgery. Furthermore, down-regulation of galectin-1 with galectin-1 siRNA significantly inhibited cell proliferation, migration and invasion in EOC cell lines. In contrast, recombinant galectin-1 or up-regulation of galectin-1 with lentivirus mediated galectin-1 cDNA transfection significantly increased migration and invasion potential in EOC cells compared with the GFP control. The correlation of fibroblast and cancer cells studied in western blot analysis reported that decrease of galectin-1 expression in fibroblasts with siRNA reduced MMP-2 expression than in controls, demonstrating that galectin-1 secreted by human fibroblast cells might affect the invasive capacity of cells. Although Zhang et al. did not find any significant difference of MMP-2 expression in SKOV3ip1 treated with galectin-1 siRNA, the down-regulation of galectin-1 in SKOV3ip1 reduced H-Ras, p-Raf-1, extracellular signal-regulated kinase (p-ERK), MMP-9 and c-Jun expression, while high expression of galectin-1 increased the expression of the above proteins ${ }^{41}$. Interestingly, it was suggested that galectin-1 may interact with H-Ras and activate ERK pathway, thus promoting malignancy of EOC by enhancing cell invasion and proliferation.

Toll like receptors (TLR) were found in various tumor types which were associated with carcinogenesis, cancer progression and metastasis ${ }^{44}$. It had been observed that the level of galectin-1 was increased by TLR activating specific ligand in ovarian cancer SKOV-3 cells, suggesting that PI3K-dependent galectin-1 production was the leading pathway of ovarian cancer metastasis after TLR stimulation 45 . Moreover, the wound healing capacity of TLR4knockdown SKOV-3 cells was attenuated by recombinant galectin-1 treatment. Down-regulation of galectin-1 with siRNA in lipopolysaccharide (LPS, 
TLR4 ligand) stimulated SKOV-3 cells by increasing the activity of MMP-2 and MMP-9 and up-regulating the mesenchymal markers. The invasion property of galectin-1 knock-down SKOV-3 ovarian cancer cells was significantly suppressed after stimulation with LPS, suggesting that TLR4 mediated PI3K activation stimulated the invasive and migratory capacity of ovarian cancer cells through galectin-1 production.

\section{Therapeutic potential of galectin-1 in ovarian cancer}

A few studies had documented the potential use of galectin-1 in treatment of ovarian cancer. Zhang et al. described the significant effect of galectin- 1 on the cisplatin-resistance in A2780/CP EOC cells ${ }^{41}$. In their study, galectin-1 was down-regulated in A2780/CP cells lines with galectin-1 siRNAs and then treated with or without cisplatin in both transfected cells and control siRNA. As a result, cisplatin inhibited cell growth and induced apoptosis in the cell lines, and transfected cells with galectin-1 siRNAs showed higher sensitivity to cisplatin compared with transfected control siRNA. Likewise, Hey (low galectin-1 expression) cells transfected with galectin-1 displayed decreased sensitivity to cisplatin compared to GFP transfectants. Furthermore, A2780/CP cells added with galectin-1 siRNA showed a decreased H-Ras, p-Raf-1, p-ERK, p21 and Bcl-2 expression evaluated by western blot analysis, whereas overexpression of galectin- 1 increased the expression of above proteins. Therefore, it implied that galectin-1 can be a potential therapeutic option contributing in cisplatin-resistance EOC cells.

OTX008 (calixarene compound) was a small particular molecule of galectin-1 inhibitor, which had been aimed for antineoplastic activity via suppression of cancer cell invasion, proliferation, and tumor angiogenesis ${ }^{46}$. Zucchetti et al. ${ }^{46}$ found that OTX008 inhibited the in vivo growth of ovarian cancer cell lines (A2780-1A9). Additionally, OTX008 potentiated the activity of the tyrosine kinase inhibitor sunitinib on A2780-1A9 in vivo and in vitro, while the combination of these two agents showed an additive antiproliferative activity, indicating that the compound targeting galectin-1 might contribute to better ovarian cancer treatment.

\section{Role of galectin-1 in the prognosis of ovarian cancer}

Galectin-1 overexpression was primarily found to be associated with increased recurrent rate in 3 -year and shorter PFS [40, 41] than those in the weak expressing EOC patients (22.5 vs 48 months). Schulz et al. ${ }^{43}$ revealed galectin-1 expression in the nuclei of ovarian cancer cells displayed no any correlation to overall survival (OS). However, galectin-1 expression in the cytoplasm of ovarian cancer cells was profoundly associated with decreased OS compared to negative galectin- 1 expression patients. In addition, their results showed that elevated expression of galectin-1 in the stromal cells was significantly related with worse outcomes compared with low galectin-1 patients. Multivariate analysis also showed that stromal galectin-1 expression was an independent prognostic factor for ovarian cancer patients.

Chen et al. ${ }^{42}$ detected considerable changes in serum galectin-1 expression among EOC patients with non-metastatic compared with metastatic disease $(69 \mathrm{ng} / \mathrm{ml}$ vs $370 \mathrm{ng} / \mathrm{ml})$. The staining of galectin-1 in cancer associated stromal cells significantly correlated with pathologic variables and International Federation of Gynecology and Obstetrics (FIGO) stages of the EOC patients. Increased galectin-1 expression in cancer stromal cells was found in lymph node metastasis and invasive carcinoma comparing with the non-invasive one. Intriguingly, 3-year recurrent rate was elevated in the patients with high galectin-1 expression compared to that in the low galectin-1 expressing patients. Thus, the combined results suggested that galectin- 1 could be a novel prognostic and progressive biomarker in EOC patients.

\section{Endometrial cancer}

\section{Expression and role of galectin-1 in endometrial carcinoma}

Van den Brule et al. 47 found that galectin-1 staining in cytoplasm of cells demonstrated a remarkable change of galectin-1 expression in normal endometrium compared to that in endometrial cancer (normal $1.09 \pm 0.54$ vs tumor $1.85 \pm 0.59$ ). Although galectin-1 expression was notably increased in cancer cells than adjacent normal endometrium, analysis of galectin-1 expression with clinicopathologic characteristics of the cancers could not yield any association among galectin-1 expression and FIGO staging, histological type or grade, lymph node status, severity of invasion, or occurrence of steroid receptors. In contrast, Mylonas et al. ${ }^{48}$ detected that galectin-1 immunoreaction was increased from G1 to G3 stage (World Health Organization grading system) of 70 endometrioid adenocarcinomas patients. In FIGO staging, galectin-1 binding was up-regulated in FIGO stage III/IV compared to FIGO stage I/II, but their results were not statistically significant. However, they found that galectin-1 binding was associated with lymphangiosis. Thus, further studies were urgently needed to elucidate the role of galectin- 1 in the pathogenesis and malignant transformation of endometrial cancer, and to evaluate the therapeutic and prognostic value of it in endometrial cancer. 


\section{The role of galectin-3 in gynecological cancers}

\section{Cervical cancer}

\section{Expression and role of galectin-3 in cervical carcinogenesis}

Real-time quantitative PCR found that expression of galectin-3 in cervical tumor cells was markedly down-regulated in contrast to healthy cervical tissues ${ }^{49}$. Subsequent immunohistochemical staining revealed a strong immunoreactivity in all the normal (10/10) cervical squamous epithelia, usually with cytoplasmic and some with nucleus and plasma membrane staining pattern. On the other hand, $80 \%$ $(32 / 40)$ of ISCCs, $70 \%(14 / 20)$ of HGSILs, and $40 \%$ $(8 / 20)$ of LGSILs revealed a low or negative galectin-3 expression in cytoplasm and membranous staining. Moreover, expression of galectin-3 in ISCCs was remarkably lower than that in healthy cervical controls and LGSILs. When four histopathologic grades (normal, LGSIL, HGSIL and ISCC) of samples were considered according to the occurrence of positive staining, galectin-3 expression was progressively declined according to the progression from LGSIL to HGSIL and ISCC. The study suggested that the decreased expression of galectin-3 was associated with the progression of cervical neoplasia. However, $\mathrm{Li}$ et al. 50 found that galectin-3 expression in cervical cancer was significantly higher than that in normal cervix, cervicitis and cervical intraepithelial neoplasia, while expression in cervical intraepithelial neoplasia was significantly higher than that in normal cervix and cervicitis. In addition, the expression of galectin-3 was related with histological grade, deep myometrial invasion and lymph node metastasis in cervical cancer patients.

Punt et al. ${ }^{31}$ displayed a positive expression of galectin-3 both in tumor cells and stromal cells of SCC in $84 \%$ samples $(n=160)$. Additionally, galectin-3 expression in strong tumor cells was documented mutually at the invasive border and center of the tumor fields which were exclusive with galectin- 1 or galectin-9 expression. Therefore, the study noted that galectin-3 expression was reduced when another type of galectin was present. Furthermore, low expression of galectin-3 was related with elevated invasion depth whereas high galectin-3 expression was associated with decreased tumor invasion. Galectin-3 expression was also correlated with the presence of human papilloma virus (HPV) type 16 and 18. However, either in the tumor epithelium or stroma, the tumor mass and the incidence of lymph node metastasis or vaso-invasion was not markedly distinct between trials with absence or presence of galectin-3 expression

A study by Liu et al. ${ }^{51}$ showed that galectin-3 interacted with vascular endothelial growth factor (VEGF) receptors and reinforced the signal transduction, inducing cervical cancer cell invasion. When galectin-3 expression was down-regulated in $\mathrm{SiHa}$ cell lines of cervical cancer by specific siRNA, VEGF-C mostly decreased its capability to raise $\mathrm{SiHa}$ cell invasion. Indeed, VEGF-C $(100 \mathrm{ng} / \mathrm{mL})$ treatment immensely augmented expression of galectin-3 from 12-48 h, which was suppressed by NF-kB inhibitors. In addition, inactivating of NF-kB subunit p65 expression with specific siRNA led to the decreased expression of galectin-3 affected by VEGF-C, illustrating that NF-kB was the important mediator for this pathway. Immunoprecipitation assay showed that VEGF-C stimulation increased interaction between galectin-3 and phosphorylated VEGF-R3 at resting state. SiHa cells treated with various doses of exogenous galectin-3 $(2,5,10 \mu \mathrm{g} / \mathrm{mL})$ for $10 \mathrm{~min}$ raised VEGF-R3 phosphorylation. Taken together, VEGF-C increased galectin-3 protein expression via NF-kB pathway, which interacted with and activated VEGF-R3 progressing to higher invasiveness of cervical cancer SiHa cells.

\section{Role of galectin-3 in the prognosis of cervical cancer}

Several studies had analyzed that high expression of galectin-3 was associated with poor prognosis in cervical cancer patients ${ }^{50,52}$. During the 5-78 months follow-up period, Li et al. ${ }^{50}$ exhibited that galectin-3 overexpression was significantly associated with decreased survival rate compared to those with low expression. Galectin-3 positive expression in cervical cancer patients with very low or negative levels of p16 (onco-protein, used as a HPV marker), was also found to be correlated with poor prognosis in OS analyses 52. Additionally, the comprehensive case control investigation of galectin-3 gene polymorphisms (rs4644, rs4652 and rs11125) demonstrated a positive prognostic correlation in Chinese cervical cancer patients ${ }^{53}$. Polymerase chain reaction-restriction fragment length polymorphism detected significantly increased distribution of the $\mathrm{CC}+\mathrm{CA}$ genotype of rs4652 and AT+TT genotype of rs11125 in the cervical cancer group compared with healthy control. Moreover, further study revealed that single-nucleotide polymorphisms in the galectin-3 gene were related to tumor diameter, FIGO stage, differentiation grade, lymph node metastasis and pathologic type. The 5-year survival rate of CC patients with an AA genotype of rs11125 in galectin-3 was markedly higher than those presented with an AT+TT genotype $(71.05 \%$ vs $42 \%)$, whereas, 5 -year survival rate of patients carrying a $\mathrm{CC}+\mathrm{CA}$ genotype 
of rs11125 was significantly lower than that of AA genotype carrier $(88.89 \%$ vs $54.63 \%)$. Consistently, recurrence rate in CC+CA genotype of rs4652 was higher compared with an AA genotype. Multivariate cox analysis illustrated that the CC+CA genotype of rs4652, the AT+TT genotype of rs11125, and treatment modality were independent factors for disease-free survival (DFS) and OS. This evidence suggested that the $C$ allele of rs4652 and the T allele of rs1125 in the galectin-3 gene may be risk factors, probably affecting the prognosis of cervical cancer patients.

\section{Ovarian cancer}

\section{Expression and role of galectin-3 in ovarian cancer}

Galectin-3 expression was primarily located in nucleus, cytoplasm of ovarian cancer cells but not in normal or healthy ovarian tissues 54-58. Higher galectin-3 expression was more common in clear cell carcinomas ${ }^{59}$, serous cystadenomas, serous borderline ovarian tumors and mucinous tumors compared to endometrioid and transitional cell tumors. In addition, higher galectin-3 expression was associated with Ki-67 and advanced stages (FIGO stage III and IV) of clear cell carcinomas ${ }^{60}$. Moreover, galectin-3 had various roles in tumorigenesis and progression of ovarian cancer. $\mathrm{Lu}$ et al. 61 exhibited that down-regulation of galectin-3 reduced migratory and invasive capability of SKOV-3 EOC cells (high galectin-3 expressing) in comparison with the control group, whereas OVCAR3 (low galectin-3 expressing) cells with increased galectin-3 expression revealed higher migratory and invasive capability. Decrease of galectin-3 in SKOV-3 cells reduced the level of components involved in the phosphorylated NF-kB pathway (IkB, IKK and p65), which explained that galectin-3 acted as an up-regulating molecule of NF-kB pathway in ovarian cancer cells. The over-expression of galectin-3 in OVCAR-3 cells through immunofluorescence technique presented the higher p65 nuclear translocation compared to the normal control type, signifying that the phosphorylation activity of p65 was enhanced with high galectin-3 expression.

Kang et al. 62 displayed that galectin-3 over-expression increased ovarian cancer cells invasion, migration and proliferation, while silencing of galectin-3 with specific siRNA reversed these biological phenomenons. Similarly, ovarian cancer growth rate was higher in galectin-3 overexpressing A2780 ovarian cancer xenografted nude mice. Additionally, galectin-3 was reported to maintain ovarian cancer stem cell properties by activating the Notch1 intracellular domain. Down-regulation of galectin-3 was noted to decrease the epithelial mesenchymal transition (stemness phenotype) regulators and stemness factors in SKOV-3 and OVCAR-429 ovarian cancer cells. Conversely, over-expression of galectin-3 significantly enhanced the expression of Notch target genes such as Hes 1 and Hey 1 and cleaved form of Notch1 intracellular domain in nuclear fractions. Furthermore, the level of galectin was significantly decreased with silencing of galectin-3 gene, suggesting that galectin- 3 modulated stemness factors via Notch signaling pathway and increased the cleavage and the nuclear translocation of NICD1 in ovarian cancer cells. Moreover, increased expression of galectin-3 was detected in advanced stages, compared to stage I or II in ovarian cancer patients, suggesting that galectin-3 supported stemness of these cells. Eliaz et al. ${ }^{62}$ also found that galectin-3 expression was enhanced in stage IV than in stage I ovarian cancer, confirming the theory that galectin-3 might promote ovarian malignancy. In stage IV ovarian cancer, high expression of galectin-3 was co-existed with acute inflammation, cancer metastasis, and increased C-reactive protein, which became normal after tumor was controlled with chemotherapy. Compared to the control case, Hossein et al. ${ }^{63}$ found that administration of recombinant human galectin-3 resulted in $41 \%$ increase in cell proliferation, $33.6 \%$ increase in substrate-dependent adhesion and $36 \%$ decrease in caspase- 3 activity of SKOV-3 ovarian cells.

\section{Therapeutic potential of galectin-3 in ovarian cancer}

Cai et al. 64 identified significant associations between serum galectin-3 level and paclitaxel resistance phenotype in patients with ovarian cancer. Then, this study elucidated that exogenous galectin-3 might induce paclitaxel resistance in SKOV-3 and ES-2 cells through toll-like receptor 4 signaling activation accompanied by inhibition of toll-like receptor 4- and caveolin-1 interaction, revealing a novel insight into paclitaxel resistance induction. Co-treatment with galectin-3 siRNA and paclitaxel showed an enhanced cytotoxic effect compared with treatment with paclitaxel alone in SKOV3 cells, which suggested that galectin-3 expression may be involved in regulating the response to paclitaxel-based chemotherapy and galectin-3 siRNA could increase the sensitivity to paclitaxel treatment in EOC cells ${ }^{54}$. Likewise, over-expression of galectin-3 markedly inhibited the cisplatin and paclitaxel-induced cell death and paclitaxel-promoted apoptosis in A2780 cells, whereas down-regulation of galectin-3 increased paclitaxel-induced apoptosis in SKOV-3 cells ${ }^{62}$.

$0.1 \%$ PectaSol-C modified citrus pectin (a specific galectin-3 competitive inhibitor) combined with non-effective dose of paclitaxel $(100 \mathrm{nM})$ exerted a synergistic effect on reducing cell viability and 
subsequent increasing caspase-3 activity in SKOV-3 cells. Moreover, there was a significant decrease in substrate-dependent adhesion in combination group, suggesting that inhibition of galectin- 3 could be a useful therapeutic tool for combination therapy of ovarian cancer ${ }^{63}$. Mirandola et al. ${ }^{56}$ produced a truncated, dominant-negative form of Galectin-3, namely Galetic-3C, which was further applied in ovarian cancer cell lines and primary cells established from ovarian cancer patients. The study demonstrated that Galectin-3C significantly reduced the growth, motility, invasion, and angiogenic potential of cultured ovarian cancer cell lines and primary cells, which indicated that Galectin-3C was a promising new compound for the treatment of ovarian cancer.

Lu et al. ${ }^{61}$ found that through the knockdown of galectin-3 by small interfering RNA, the apoptosis of ovarian cancer cells and the sensitivities to carboplatin were significantly increased. However, the apoptosis of cancer cells and sensitivity to carboplatin were decreased via up-regulation of galectin-3 caused by plasmid transfection, which acted through the nuclear factor-kappa B pathway. This result indicated that low galectin-3 level improved the chemo-sensitivity to carboplatin in EOC. The expression of galectin-3 in clear cell carcinoma of ovary might contribute to its lower cell proliferation and lead to cisplatin resistance 59. After knocking down galectin-3 in three cell lines from human clear cell carcinoma of ovary: RMG-I, KK and HAC-2 cell lines, cisplatin-induced apoptosis was increased. Combined results indicated that galectin-3 could be a novel potential therapeutic target in various ovarian cancers and might affect the chemo-sensitivity to common chemotherapeutic drugs.

\section{Role of galectin-3 in the prognosis of ovarian cancer}

Using log-rank test, Brustmann et al. ${ }^{57}$ found that galectin-3 immuno-expression was not correlated to survival of serous ovarian cancer. However, Kim et al. ${ }^{57}$ found that high cytoplasmic galectin-3 immunoexpression was associated with shorter PFS in patients with ovarian serous carcinomas, which indicated that cytoplasmic galectin-3 immunostaining might be an adjunct in the identification of high-risk ovarian serous cancers. With regard to clear cell carcinoma of ovary, galectin-3 expressions were not related with OS and DFS both in univariate and multivariate analyses of 144 patients ${ }^{60}$.

In the study reported by Anastasi et al. 58, galectin-3 was combined with multi-detector contrast enhanced computed tomography to predict recurrence of EOC disease. The results showed a significant correlation between high serum galectin-3 levels and disease recurrence, especially with the presence of local recurrence, carcinomatosis, lymphadenopathies and distant metastasis. However, galectin-3 overexpression in the cytoplasm and peritumoral stroma was not associated with poor outcome of ovarian cancer patients. Patients with high level of galectin-3 staining other than in nuclei showed significantly decreased OS compared to patients with nuclear staining. Therefore, nuclear galectin-3 expression may be considered as a positive prognostic factor in ovarian cancer patients ${ }^{43}$.

\section{Endometrial cancer}

\section{Expression and role of galectin-3 in endometrial cancer}

Galectin-3 expression in endometrial cancer was reduced compared with normal or benign menopausal endometrium (normal, $2.0 \pm 0.5$ vs tumor $1.40 \pm 0.68) 47,65$. Decreased expression of galectin-3 may be involved in the pathogenesis of endometrial carcinomas from normal endometrium to carcinoma 66. Galectin-3 expression in the cancer cells was reported mostly in the cytoplasm, nucleus and membrane 66, 67. Al-Maghrabi et al. explored the galectin-3 immunohistochemical phenotype and its association with clinicopathological factors in the carcinoma of endometrium and found that galectin-3 immunoreactivity was significantly associated with tumor grade, stage and differentiation. Membranous and cytoplasmic galectin-3 staining were significantly associated with grade I and stage II, while cases with loss of staining were more frequent in grade II, III and poorly differentiated tumors, supporting the tumor suppression role of galectin-3 in endometrial carcinoma 66,67. Ege et al. [66] documented that in the cases with lymph node metastasis, $64 \%(7 / 11)$ of them were low and $36 \%(4 / 11)$ cases were high for galectin-3 expression in stroma, whereas in patients without lymph node metastasis, $18 \%$ (7/39) were negative and $82 \%(32 / 39)$ were positive for galectin-3 expression in stroma, suggesting that decreased level of stromal galectin-3 expression might be an index of lymph node metastasis in endometrial cancer.

In contrast, using immunohistochemistry to detect the expression of galectin-3 in 101 curettage specimens, Brustmann et al. ${ }^{68}$ found that nuclear galectin-3 immunostaining in endometrial tissues was significantly increased from normal endometrium, simple hyperplasia, complex hyperplasia and atypical hyperplasia to endometrioid adenocarcinoma. Galectin-3 expression increased with tumor grade in endometrioid adenocarcinoma. In addition, galectin-3 nuclear expression in endometrial tissues in serous papillary carcinoma and clear cell carcinoma were significantly higher than that in endometrioid adenocarcinoma. Although enhanced nuclear galectin-3 
expression was noted in carcinomas, immunostaining of galectin-3 in stromal cells decreased in the latter. In a recent study, Lambropoulou et al. ${ }^{69}$ exhibited that a high galectin-3 expression was correlated with age $>57$, non-endometrioid histological type and elevated levels of cysteine-rich intestinal protein 1 , which was involved in cancer cell growth and differentiation ${ }^{70}$. After silencing of galectin-3 expression in endometrial cancer cell RL95-2 by RNA interference technology using galectin-3 specific small RNA, S-phase cells, the cells adhesive ability to fibronectin, and integrin $\beta 1$ expression were significantly reduced, but G1 phase cells were increased, suggesting that galectin-3 might promote cell proliferation and adhesion in endometrial cancer ${ }^{71}$.

\section{Role of galectin-3 in prognosis of endometrial cancer}

In a Kaplan-Meier study, the mean survival time in endometrial cancer patients was decreased with the increasing expression of galectin-3 ${ }^{69}$. The log-rank test for galectin-3 expression revealed that the survival time variation between negative and positive galectin-3 expression as well as between low and high galectin-3 expression was statistically significant. Additionally, mortality was $0 \%$ in patients with mild expression of galectin-3 and was significantly increased $(88.9 \%)$ in patients with high galectin-3 expression. Five-year survival for patients with low or moderate expression of both galectin-3 and cysteinerich intestinal protein 1 was $100 \%$, while either of the two proteins with higher expression was $33.3 \%$, and both proteins with higher expression was $16.6 \%$. It was suggested that galectin-3 was related with poor prognosis and shorter survival rate in endometrial cancer patients.

\section{The role of galectin-7 in gynecological cancers}

\section{Cervical cancer}

\section{Expression and role of galectin-7 in cervical cancer}

The positive immunostaining rate for galectin-7 was gradually decreased from normal cervical tissue to intraepithelial neoplasia and to cervical squamous carcinoma. Galectin-7 was significant negative associated with lymph node metastasis and staging of cervical squamous carcinoma. Multivariate analysis with the Cox's proportional hazards model indicated that galectin-7 had significant protective effect on cervical squamous carcinoma patients. Subsequent in vitro studies in $\mathrm{SiHa}$ and $\mathrm{C} 33 \mathrm{~A}$ human cervical squamous carcinoma cell lines revealed that knocking down galectin-7 significantly promoted migration and tumor cell viability. These evidences suggested that galectin-7 played important protective roles in cervical squamous carcinoma 72,73 .

However, Park et al. 74 demonstrated that galectin-7-transfected HeLa cells exhibited increased invasion and up-regulated MMP-9 expression. Upon transfection HeLa cells with galectin-7, p38 MAPK was activated, and SB203580, a chemical inhibitor of p38 MAPK, reversed the effects of galectin-7. Hence, it suggested that galectin-7 induced the transformation of HeLa cells to more invasive cells via elevating MMP-9 expression, which may be related to p38 MAPK signaling pathway.

\section{Therapeutic potential of galectin-7 in cervical cancer}

In $\mathrm{SiHa}$ and C33A human cervical squamous carcinoma cell lines, $\mathrm{Zhu}$ et al. ${ }^{72}$ revealed that knocking down galectin-7 enhanced tumor cell viability against paclitaxel-induced apoptotic stress, likely through increasing the MMP-9 expression and activating the phosphatidylinositol 3-kinase/Akt signaling pathway, respectively. It was provided that galectin-7 expression could increase the chemosensitivity to paclitaxel in cervical cancer cells.

The proteomic analysis showed that increased galectin-7 expression was significantly associated with increased sensitivity to concurrent chemoradiotherapy (CCRT) in cervical cancer ${ }^{72}$. Subsequent western blot and tissue microarray with immunohistochemistry staining revealed that galectin-7 expression was considerably higher in the CCRThighly sensitive group compared with that in the CCRT-lowly sensitive group. This provided the information that galectin-7 expression may be used as a predictive factor of increased response to CCRT in cervical cancer patients. In addition, pretreatment levels of galectin-7 predicted radiation response in patients with cervical squamous cell carcinoma 72 . Elevated galectin-7 expression was associated with improved outcomes after radiation therapy for cervical cancer patients.

\section{Role of galectin-7 in the prognosis of cervical cancer}

Elevated galectin-7 expression was related with improved clinical outcomes after radiation therapy for cervical cancer ${ }^{75}$. In the study of 161 SCC (FIGO stage IB-IIB) patients treated with definitive radiation therapy, Tsai et al. ${ }^{75}$ revealed that positive galectin-7 expressions were correlated with advanced disease (53 patients, $37 \%$ had stage IIA or IIB) than patients with negative galectin-7 expressions. However, five-year OS rate was markedly improved in high galectin-7 expression patients compared with galectin-7 negative expression patients ( $64 \%$ vs $36 \%$ ). Similarly, distant metastasis free survival (DMFS) and disease-specific survival (DSS) rate for patients with positive galectin-7 tumors were higher than in 
negative galectin-7 tumors, which was $73 \%$ vs $55 \%$, and $65 \%$ vs $36 \%$, respectively. In multivariate analysis, adjusting for age, stage, and tumor diameter, galectin-7 expression remained a significant predictor of OS (hazard ratio $=0.34, P=0.001$ ), DMFS (hazard ratio $=0.43, P=0.03$ ), and DSS (hazard ratio $=0.34, P$ $=0.001$ ).

Although none of these four proteins (S100A9, galectin-7, NMP-238 and HSP-70) could be utilized as an independent predictive factor for the relapse of cervical cancer after CCRT, a recurrence prediction model was generated by combining increased S100A9 and galectin-7 expressions, and decreased NMP-238 and HSP-70 expressions as a full predictive factor ${ }^{72}$. In their following experiments, Zhu et al. ${ }^{73}$ found that cervical squamous carcinoma patients with negative staining of galectin-7 or S100A9 showed significantly lower 5-year OS rate than those with positive staining. Multivariate analysis with the Cox's proportional hazards model indicated that both galectin-7 and S100A9 had significant protective effects on cervical squamous carcinoma patients. Higareda-Almaraz et al. ${ }^{76}$ also found that galectin-7 expression presented a significantly better survival rate of patients diagnosed with cervical cancer. Tumors with combined high galectin-7 and low galectin-1 expressions presented significantly better prognoses.

\section{Ovarian cancer}

\section{Expression and role of galectin-7 in ovarian cancer}

Galectin-7 was not detected in normal ovarian tissues, while positive cytoplasmic staining of galectin-7 was detected in epithelial cells in all EOC histological subtypes ${ }^{43}$. After evaluating galectin-7 immuno-staining in the cytoplasm and nucleus of cancer cells as well as the peritumoral stroma in 156 ovarian cancer specimens, Schulz et al. ${ }^{43}$ found that galectin-7 was only present in the cytoplasm of tumor cells. However, in Kim's study 77, immunohistochemical analysis revealed that galectin-7 expression was primarily detected in nuclei and occasionally in the nucleus and cytoplasm of tumor cells in 63 formalin-fixed, paraffin-embedded EOC tissues. High galectin-7 expression was associated with greater age, advanced grade tumors and metastatic samples 43 . The median age was approximately nine years older in patients with the high galectin-7 expression than low expression. In addition, the residual tumor volume was larger in the high-expression group compared to the low-expression group.

Galectin-7 expression in human EOC cell lines was induced by mutant p53 ${ }^{43}$. Down-regulation of galectin-7 using siRNA resulted in the inhibition of cell proliferation in ovarian cancer cell lines ${ }^{43}$. In addition to involvement in cell proliferation, galectin-
7 increased the invasive behavior of ovarian cancer cells by inducing MMP-9 and increasing cell motility. Invasive effects of ovarian cancer cells were enhanced by both intracellular and extracellular galectin-7 ${ }^{43}$. EOC cells can also secrete galectin-7. Intracellular galectin-7 expression in ovarian cancer cells resulted from an autocrine transcriptional mechanism and endocytosis of extracellular galectin-7, suggesting that extracellular galectin-7 played a central role in controlling intracellular galectin-7 in EOC cells ${ }^{43}$.

\section{Role of galectin-7 in the prognosis of ovarian cancer}

High galectin-7 expression was associated with high mortality and poor OS outcome in patients with EOC, especially ovarian serous cystadenocarcinoma 43. Kim et al. 77 showed that median OS in low galectin-7 expressing patients was 72 months, while in patients with high galectin-7 expression was only 56 months. Using either univariate analysis or multivariate analysis, they concluded that galectin-7 expression could be used as an independent prognostic factor for poor OS in ovarian cancer patients. Schulz et al. ${ }^{43}$ also confirmed cytoplasmic galectin-7 expression as a negative prognostic factor for ovarian cancer. They observed a significantly reduced OS for cases with high galectin-7 expression and a better survival for galectin-7 negative cases, when compared to cases with low expression of galectin-7.

\section{The role of galectin-9 in gynecological cancers}

\section{Cervical cancer}

\section{Expression and role of galectin-9 in cervical cancer}

Galectin-9 immunostaining was evidently detected in normal epithelium and endocervical glands, but significantly faint in cervical intraepithelial neoplasia and SCC 78. Moreover, the galectin-9 expression in high-grade squamous intraepithelial lesions was significant lower than those in low-grade squamous intraepithelial lesions, indicating that reduced galectin-9 expression was associated with malignant transformation. Furthermore, galectin-9 expression in well-differentiated SCC was significantly higher compared to those in poorly differentiated SCC, implying the possible involvement of galectin-9 in the differentiation of SCC. However, galectin-9 expression was not different among the FIGO stage ${ }^{78}$. Punt et al. also found that galectin-9 was only expressed by tumor cells in 11\% cases of SCC tissues 31. Indeed, galectin-9 expression was significantly correlated with the presence of HPV type 16 or 18 . Tumor size and the presence of vaso-invasion or lymph node metastasis were not significantly 
different between samples with or without expression of galectin-9 either in the tumor epithelium or stroma. But expression of galectin-9 in tumor cells showed a trend toward improved survival.

\section{Ovarian cancer}

\section{Expression and role of galectin-9 in ovarian cancer}

Low galectin-9 expression was detected in ovarian stromal cells of normal ovarian tissues, while galectin-9 staining was mostly found in the cytoplasm of ovarian cancer cells, rather than at nuclei or the peritumoral stroma 79 . Cases with high galectin-9 expression presented a significant association with low tumor stage, early FIGO stage, and younger age. Kaplan-Meier analysis showed that moderate galectin-9 expression had a decreased PFS and OS compared to galectin-9 negative cases. Intriguingly, patients with high galectin-9 expression displayed the best PFS and OS. Thus, it was recommended that galectin-9 expression determined the outcome of ovarian cancer patients in two opposing ways.

\section{Conclusion}

Galectins regulate various crucial mechanisms that are essential for maintaining cell homeostasis. In conclusion, galectins $-1,-3,-7$ and -9 have been awarded a key role in tumorigenesis and progression in human gynecological cancers (summarized in Table 1). Furthermore, multiple studies have demonstrated that deregulation of these proteins at cellular levels could inhibit cancer proliferation and invasion with diverse mechanisms. Additionally, it is recommended that some certain chemotherapy resistances are induced by these lectins. Moreover, circulating galectins concentration could be potential prognostic factors for various gynecological cancers. Therefore, targeting these 4 galectins might become a potent therapeutic strategy for treatment in gynecological malignancies. Novel compounds or inhibitors targeting galectins could be designed to exert anticancer properties on gynecologic cancers in the future. However, due to the fact that there are some conflicting evidence of these galectins existing in cervical, ovarian and endometrial cancers, further researches should be carried out to investigate the detailed function of it in gynecologic carcinomas.

Table 1. The expression and the role of Galectin-1, -3, -7 and -9 in tumor progression, treatment, and prognosis of gynecological cancers.

\begin{tabular}{|c|c|c|c|}
\hline Cancer types & Expression and role & Treatment and effect & Prognostic significance \\
\hline \multirow{3}{*}{$\begin{array}{l}\text { Cervical } \\
\text { cancer }\end{array}$} & $\begin{array}{l}\text { Galectin 1: } \\
\text { High galectin-1 was detected in cytoplasm, nuclei } \\
\text { and stroma of cervical cancer cells, while galectin-1 } \\
\text { expression was negative or absent in normal } \\
\text { cervical tissue samples }{ }^{35} \text {. } \\
\text { Increased galectin-1 expression was associated with } \\
\text { lymph node metastasis and tumor invasion }{ }^{31} \text {. } \\
\text { Galectin-1 expression in stromal cells was gradually } \\
\text { increased according to the pathological grade i.e. } \\
\text { from normal cervical tissues to LGSIL, HGSIL and } \\
\text { ISCC }{ }^{34} \text {. }\end{array}$ & 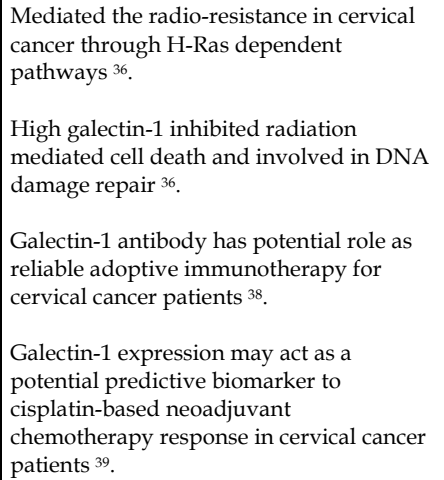 & $\begin{array}{l}\text { Galectin-1 expression was not associated with the } 5 \text {-year } \\
\text { progression free survival }{ }^{32} \text {. } \\
\text { Galectin-1 expression in squamous cervical cancer cells } \\
\text { was associated with both } 10 \text {-year local recurrence and } \\
10 \text {-year cancer specific survival, but could not predict } \\
\text { distant metastasis }{ }^{34} \text {. } \\
\text { Strong expression of galectin- } 1 \text { by tumor cells was } \\
\text { significantly correlated with poor disease-free and } \\
\text { disease-specific survival in patients with squamous } \\
\text { cervical cancer }{ }^{31} \text {. }\end{array}$ \\
\hline & 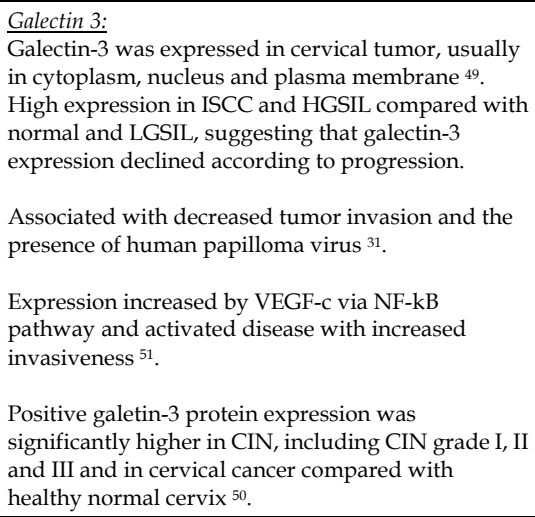 & N/A & $\begin{array}{l}\text { High expression of galectin-3 is associated with poor } \\
\text { prognosis } 50,52 \\
\text { Overexpression of galectin-3 was significantly associated } \\
\text { with decreased survival rate compared to those with low } \\
\text { expressions }{ }^{50} \text {. The } 5 \text {-year survival rate of CC patients } \\
\text { with an AA genotype of rs } 11125 \text { in galectin-3 was } \\
\text { markedly higher than those presented with an AT+TT } \\
\text { genotype }(71.05 \% \text { vs } 42 \%) \text {, whereas, } 5 \text {-year survival rate } \\
\text { of patients carrying a CC+CA genotype of rs } 11125 \text { was } \\
\text { significantly lower than that of AA genotype carrier } \\
(88.89 \% \text { vs } 54.63 \%)^{52} \text {. }\end{array}$ \\
\hline & $\begin{array}{l}\text { Galectin 7: } \\
\text { High expression documented in cytoplasm and } \\
\text { nuclei of cancer cells. Healthy cervical tissue } \\
\text { compared with CIN II }(40.4 \%), \text { CIN III (13.9\%) and } \\
\text { SCC tissue showed a significant decrease in the high } \\
\text { staining proportion of galectin-7. Galectin-7 } \\
\text { knock-down significantly promoted invasion }\end{array}$ & $\begin{array}{l}\text { Galectin- } 7 \text { increased the sensitivity to } \\
\text { concurrent chemo-radiotherapy in cervical } \\
\text { cancer and can act as a protective } \\
\text { therapeutic role } 72,73 \text {. }\end{array}$ & $\begin{array}{l}\text { Galectin-7 high expression was correlated with better } \\
\text { clinical outcomes following radiation treatment for } \\
\text { cervical cancer. Negative galectin-7 expression was } \\
\text { related with decrease rate of DMFS, DSS and OS } 75,76 \text {. } \\
\text { SCC patients with negative galectin-7 staining had }\end{array}$ \\
\hline
\end{tabular}




\begin{tabular}{|c|c|c|c|}
\hline & $\begin{array}{l}\text { through increasing MMP-9 expression and } \\
\text { activating P13K/ Akt signaling pathway }{ }^{72,73} \text {. } \\
\text { Hela cells expressing galectin-7 were more invasive } \\
\text { than HeLa cells. Galectin-7 expression induced the } \\
\text { transformation of HeLa cells in cervical } \\
\text { adenocarcinoma to more invasive cells via MMP-9 } \\
\text { in association with p38 signaling pathway }{ }^{74} \text {. }\end{array}$ & & $\begin{array}{l}\text { profoundly decreased } 5 \text {-year OS rate compared with } \\
\text { positive staining }{ }^{73} \text {. }\end{array}$ \\
\hline & $\begin{array}{l}\text { Galectin 9: } \\
\text { Galectin-9 was detected in normal epithelium and } \\
\text { endocervical glands but those in CIN and SCC were } \\
\text { significantly faint. Galectin-9 in WSCC was } \\
\text { significantly high compared to those in HSIL. } \\
\text { Galectin-9 in SCC was inversely correlated with the } \\
\text { grade of differentiation (WSCC >> MSCC >> PSCC) } \\
78 \text {. } \\
\text { Galectin-9 was expressed by tumor cells in } 11 \% \text { of } \\
\text { samples. Tumor cell expression of galectin- } 9 \\
\text { showed a trend toward improved survival } 31 \text {. }\end{array}$ & $\mathrm{N} / \mathrm{A}$ & $\mathrm{N} / \mathrm{A}$ \\
\hline \multirow[t]{3}{*}{$\begin{array}{l}\text { Ovarian } \\
\text { cancer }\end{array}$} & $\begin{array}{l}\text { Galectin 3: } \\
\text { Predominatly located in nuclei and cytoplasm of } \\
\text { ovarian cancer cells but absent in normal or healthy } \\
\text { tissues } 54-58 \text {. } \\
\text { Associated with Ki-67L1 and FIGO stage III and IV } \\
\text { compared to stage I and II of CCCs }{ }^{60} \text {. } \\
\begin{array}{l}\text { Overexpression led to increase cells invasion, } \\
\text { migration, proliferation and modulated stemness } \\
\text { factor, while down-regulation of galectin-3 with } \\
\text { specific siRNA reversed those biological } \\
\left.\text { phenomenon [ }{ }^{60} 61,62\right] .\end{array}\end{array}$ & $\begin{array}{l}\text { High galectin-3 up-regulated the release of } \\
\text { cytokines (IL-6 and IL-8) and inhibited the } \\
\text { cisplatin and paclitaxel-mediated cell } \\
\text { death }{ }^{62,64} \text {. } \\
\text { Increases sensitivity to paclitaxel } \\
\text { treatment and galectin-3C blocked } \\
\text { angiogenesis } 54,56,63 \text {. } \\
\text { Low galectin-3 augmented the response of } \\
\text { ovarian cancer cells to carboplatin }{ }^{61} \text {. }\end{array}$ & $\begin{array}{l}\text { High galectin- } 3 \text { was correlated with poor PFS compared } \\
\text { with reduced galectin-3 expression } 54,57 \text {. } \\
\text { Galectin-3 was significantly associated with disease } \\
\text { recurrence, especially with the presence of local } \\
\text { recurrence, carcinomatosis, lymphoadenpathies and } \\
\text { distant metastasis. High level of galectin-3 staining other } \\
\text { than in nuclei showed significantly decreased OS } \\
\text { compared to patients with nuclear staining } 43,58 \text {. }\end{array}$ \\
\hline & $\begin{array}{l}\text { Galectin 7: } \\
\text { Highly expressed in the cytoplasm and nuclei. } \\
\text { Stronger expression was revealed in serous type and } \\
\text { weakest in endometrioid type. It was associated } \\
\text { with larger tumor volume and increased } \\
\text { proliferation rate compared with low galectin-7 } \\
\text { expression }{ }^{43} \text {. } \\
\text { Galectin-7 was markedly higher with advanced } \\
\text { grade, borderline and metastatic tumors of EOC in } \\
\text { contrast to benign tumors } 77 \text {. }\end{array}$ & N/A & $\begin{array}{l}\text { Galectin-7 expression indicated poor prognosis in ovarian } \\
\text { cancer with high mortality and decreased overall survival } \\
\text { outcomes. High galectin-7 expression was successively } \\
\text { independent prognostic factors for poor OS in EOC } \\
\text { patients } 77 \text {. } \\
\text { Low galectin-7 markedly correlated with favorable OS } \\
\text { and increased galectin-7 expression is conferred as an } \\
\text { independent prognostic factor for OS in ovarian cancer } 43 \text {. }\end{array}$ \\
\hline & $\begin{array}{l}\text { Galectin 9: } \\
\text { Galectin-9 staining was mostly found in the } \\
\text { cytoplasm of ovarian cancer cells. Cases with high } \\
\text { galectin-9 expression presented a significant } \\
\text { association with low tumor stage, early FIGO stage, } \\
\text { and younger age }{ }^{79} \text {. }\end{array}$ & N/A & $\begin{array}{l}\text { Kaplan-Meier analysis showed that moderate galectin-9 } \\
\text { expression had a decreased PFS and OS compared to } \\
\text { galectin-9 negative cases. Intriguingly, patients with high } \\
\text { galectin-9 expression displayed the best PFS and OS } 79 .\end{array}$ \\
\hline \multirow[b]{2}{*}{$\begin{array}{l}\text { Endometrial } \\
\text { cancer }\end{array}$} & $\begin{array}{l}\text { Galectin 1: } \\
\text { Galectin-1 expression was notably elevated in } \\
\text { cytoplasm of cancer cells than adjacent normal } \\
\text { endometrium }{ }^{47} \text {. }\end{array}$ & N/A & $\mathrm{N} / \mathrm{A}$ \\
\hline & $\begin{array}{l}\text { Galectin 3: } \\
\text { Galectin-3 expression in endometrial cancer was } \\
\text { reduced compared with normal or benign } \\
\text { menopausal endometrium } 47,65 \text {. } \\
\text { Expression in endometrial cancer was reduced } \\
\text { compared with normal or benign menopausal } \\
\text { endometrium. Mostly in the cytoplasm and/or } \\
\text { nucleus and membrane. Elevated galectin-3 } \\
\text { immunostaining was documented more frequently } \\
\text { with increased age and grade I, whereas loss or } \\
\text { decreased expression was noted in grade II and III }\end{array}$ & $\mathrm{N} / \mathrm{A}$ & $\begin{array}{l}\text { Galectin-3 is related with poor prognosis and shorter } \\
\text { survival rate in endometrioid cancer patients } 69 .\end{array}$ \\
\hline
\end{tabular}




\begin{tabular}{|l|l|l|}
\hline $\begin{array}{l}\text { or poorly differentiated cancers } 66,67 . \\
\text { High expression of galectin-3 promotes cell } \\
\text { adhesion, cell growth cycle and cell proliferation in } \\
\text { cancer cell } 71 .\end{array}$ & & \\
$\begin{array}{l}\text { Galectin-3 expression increased from normal } \\
\text { endometrium (NE), simple hyperplasia (SH), } \\
\text { complex hyperplasia (CH) and Atypical hyperplasia } \\
\text { (AH) to the adenocarcinoma 68. }\end{array}$ & & \\
\hline $\begin{array}{l}\text { Galectin 7: } \\
\text { N/A }\end{array}$ & N/A & N/A \\
\hline Galectin 9: & N/A & N/A \\
\hline N/A
\end{tabular}

Abbreviations: LGSIL, low grade squamous intraepithelial lesion; HGSIL, high grade squamous intraepithelial lesion; CIN, cervical intraepithelial neoplasia; SCC, squamous cell carcinoma; ISCC, invasive squamous cell carcinoma; WSCC, well-differentiated SCC; MSCC, moderately differentiated SCC; PSCC, poorly differentiated SCC; EOC, epithelial ovarian cancer; FIGO, international federation of gynecology and obstetrics stage; DMFS, distant metastasis free survival; DSS; disease-specific survival; OS, overall survival; PFS, progression-free survival.

\section{Acknowledgements}

This work was supported by grants from Key Lab of Wenzhou City-Gynecological Oncology (No. ZD201603) and Center for Uterine Cancer Diagnosis \& Therapy Research of Zhejiang province.

\section{Human and animal Rights and Informed consent}

This article does not contain any studies with human or animal subjects performed by any of the authors.

\section{Competing Interests}

The authors have declared that no competing interest exists.

\section{References}

1. Barrow H, Guo X, Wandall HH, Pedersen JW, Fu B, Zhao Q, et al. Serum galectin-2, -4 , and -8 are greatly increased in colon and breast cancer patients and promote cancer cell adhesion to blood vascular endothelium. Clinical cancer research : an official journal of the American Association for Cancer Research. 2011; 17: 7035-46.

2. Rabinovich GA, Toscano MA. Turning 'sweet' on immunity: galectin-glycan interactions in immune tolerance and inflammation. Nature reviews Immunology. 2009; 9: 338-52

3. Ahmed H, Vasta GR. Galectins: conservation of functionally and structurally relevant amino acid residues defines two types of carbohydrate recognition domains. Glycobiology. 1994; 4: 545-8.

4. Hughes RC. Secretion of the galectin family of mammalian carbohydrate-binding proteins. Biochimica et biophysica acta. 1999; 1473: $172-85$.

5. Di Lella S, Sundblad V, Cerliani JP, Guardia CM, Estrin DA, Vasta GR, et al. When galectins recognize glycans: from biochemistry to physiology and back again. Biochemistry. 2011; 50: 7842-57.

6. Ideo H, Seko A, Yamashita K. Recognition mechanism of galectin-4 for cholesterol 3-sulfate. The Journal of biological chemistry. 2007; 282: 21081-9.

7. Ahmad N, Gabius HJ, Andre S, Kaltner H, Sabesan S, Roy R, et al. Galectin-3 precipitates as a pentamer with synthetic multivalent carbohydrates and forms heterogeneous cross-linked complexes. The Journal of biological chemistry. 2004; 279: 10841-7.

8. Hsu YL, Hung JY, Chiang SY, Jian SF, Wu CY, Lin YS, et al. Lung cancer-derived galectin-1 contributes to cancer associated fibroblast-mediated cancer progression and immune suppression through TDO2/kynurenine axis. Oncotarget. 2016; 7: 27584-98.

9. Labrie M, Vladoiu M, Leclerc BG, Grosset AA, Gaboury L, Stagg J, et al A Mutation in the Carbohydrate Recognition Domain Drives a Phenotypic Switch in the Role of Galectin-7 in Prostate Cancer. PloS one. 2015; 10: e0131307.

10. Sakaki M, Oka N, Nakanishi R, Yamaguchi K, Fukumori T, Kanayama HO. Serum level of galectin-3 in human bladder cancer. The journal of medical investigation : JMI. 2008; 55: 127-32.

11. Kim SJ, Hwang JA, Ro JY, Lee YS, Chun KH. Galectin-7 is epigeneticallyregulated tumor suppressor in gastric cancer. Oncotarget. 2013; 4: 1461-71.

12. Chawla S, Warren TA, Wockner LF, Lambie DL, Brown IS, Martin TP, et al. Galectin-1 is associated with poor prognosis in patients with cutaneous head and neck cancer with perineural spread. Cancer immunology, immunotherapy : CII. 2016; 65: 213-22.

13. Barondes $\mathrm{SH}$, Castronovo V, Cooper DN, Cummings RD, Drickamer K, Feizi $\mathrm{T}$, et al. Galectins: a family of animal beta-galactoside-binding lectins. Cell. 1994; 76: 597-8.

14. Camby I, Le Mercier M, Lefranc F, Kiss R. Galectin-1: a small protein with major functions. Glycobiology. 2006; 16: 137r-57r.

15. Huang YJ, Shiau AL, Chen SY, Chen YL, Wang CR, Tsai CY, et al. Multivalent structure of galectin-1-nanogold complex serves as potential therapeutics for rheumatoid arthritis by enhancing receptor clustering. European cells \& materials. 2012; 23: 170-81; discussion 81.

16. Thijssen VL, Griffioen AW. Galectin- 1 and -9 in angiogenesis: a sweet couple. Glycobiology. 2014; 24: 915-20.

17. Hernandez JD, Nguyen JT, He J, Wang W, Ardman B, Green JM, et al. Galectin-1 binds different CD43 glycoforms to cluster CD43 and regulate T cell death. Journal of immunology (Baltimore, Md : 1950). 2006; 177: 5328-36.

18. Perillo NL, Pace KE, Seilhamer JJ, Baum LG. Apoptosis of T cells mediated by galectin-1. Nature. 1995; 378: 736-9.

19. Chung CD, Patel VP, Moran M, Lewis LA, Miceli MC. Galectin-1 induces partial TCR zeta-chain phosphorylation and antagonizes processive TCR signal transduction. Journal of immunology (Baltimore, Md : 1950). 2000; 165: 3722-9.

20. Brewer CF, Miceli MC, Baum LG. Clusters, bundles, arrays and lattices: novel mechanisms for lectin-saccharide-mediated cellular interactions. Current opinion in structural biology. 2002; 12: 616-23.

21. Rabinovich GA, Baum LG, Tinari N, Paganelli R, Natoli C, Liu FT, et al. Galectins and their ligands: amplifiers, silencers or tuners of the inflammatory response? Trends in immunology. 2002; 23: 313-20.

22. Henderson NC, Sethi T. The regulation of inflammation by galectin-3. Immunological reviews. 2009; 230: 160-71.

23. Seddon M, Looi $\mathrm{YH}$, Shah AM. Oxidative stress and redox signalling in cardiac hypertrophy and heart failure. Heart (British Cardiac Society). 2007; 93: 903-7.

24. Markowska AI, Liu FT, Panjwani N. Galectin-3 is an important mediator of VEGF- and bFGF-mediated angiogenic response. The Journal of experimental medicine. 2010; 207: 1981-93.

25. Fortuna-Costa A, Gomes AM, Kozlowski EO, Stelling MP, Pavao MS. Extracellular galectin-3 in tumor progression and metastasis. Frontiers in oncology. 2014; 4: 138 .

26. Sato $M$, Nishi $N$, Shoji $H$, Kumagai $M$, Imaizumi $T$, Hata $Y$, et al. Quantification of galectin-7 and its localization in adult mouse tissues. Journal of biochemistry. 2002; 131: 255-60.

27. St-Pierre Y, Campion CG, Grosset AA. A distinctive role for galectin-7 in cancer ? Frontiers in bioscience (Landmark edition). 2012; 17: 438-50.

28. Kaur M, Kaur T, Kamboj SS, Singh J. Roles of Galectin-7 in Cancer. Asian Pacific journal of cancer prevention : APJCP. 2016; 17: 455-61.

29. Tureci O, Schmitt H, Fadle N, Pfreundschuh M, Sahin U. Molecular definition of a novel human galectin which is immunogenic in patients with Hodgkin's disease. The Journal of biological chemistry. 1997; 272: 6416-22.

30. Tang ZH, Liang S, Potter J, Jiang X, Mao HQ, Li Z. Tim-3/galectin-9 regulate the homeostasis of hepatic NKT cells in a murine model of nonalcoholic fatty liver disease. Journal of immunology (Baltimore, Md : 1950). 2013; 190: 1788-96.

31. Punt S, Thijssen VL, Vrolijk I, de Kroon CD, Gorter A, Jordanova ES. Galectin-1, -3 and -9 Expression and Clinical Significance in Squamous Cervical Cancer. PloS one. 2015; 10: e0129119.

32. Kim HJ, Do IG, Jeon HK, Cho YJ, Park YA, Choi JJ, et al. Galectin 1 expression is associated with tumor invasion and metastasis in stage IB to IIA cervical cancer. Human pathology. 2013; 44: 62-8

33. Zou S, Shen Q, Hua Y, Jiang W, Zhang W, Zhu X. Proteomic identification of neoadjuvant chemotherapy-related proteins in bulky stage IB-IIA squamous cervical cancer. Reproductive sciences (Thousand Oaks, Calif). 2013; 20: 1356-64

34. Huang EY, Chanchien CC, Lin H, Wang CC, Wang CJ, Huang CC. Galectin-1 is an independent prognostic factor for local recurrence and survival after 
definitive radiation therapy for patients with squamous cell carcinoma of the uterine cervix. International journal of radiation oncology, biology, physics. 2013; 87: 975-82.

35. Kohrenhagen N, Volker HU, Kapp M, Dietl J, Kammerer U. Increased expression of galectin-1 during the progression of cervical neoplasia. International journal of gynecological cancer : official journal of the International Gynecological Cancer Society. 2006; 16: 2018-22.

36. Huang EY, Chen YF, Chen YM, Lin IH, Wang CC, Su WH, et al. A novel radioresistant mechanism of galectin- 1 mediated by H-Ras-dependent pathways in cervical cancer cells. Cell death \& disease. 2012; 3: e251.

37. Girardi M, Glusac E, Filler RB, Roberts SJ, Propperova I, Lewis J, et al. The distinct contributions of murine $\mathrm{T}$ cell receptor (TCR)gammadelta+ and TCRalphabeta+ $\mathrm{T}$ cells to different stages of chemically induced skin cancer. The Journal of experimental medicine. 2003; 198: 747-55.

38. Li H, Wang Y, Zhou F. Effect of ex vivo-expanded gammadelta-T cells combined with galectin-1 antibody on the growth of human cervical cancer xenografts in SCID mice. Clinical and investigative medicine Medecine clinique et experimentale. 2010; 33: E280-9.

39. Zhu H, Chen A, Li S, Tao X, Sheng B, Chetry M, et al. Predictive role of galectin-1 and integrin alpha5beta1 in cisplatin-based neoadjuvant chemotherapy of bulky squamous cervical cancer. Bioscience reports. 2017; 37.

40. Kim HJ, Jeon HK, Cho YJ, Park YA, Choi JJ, Do IG, et al. High galectin-1 expression correlates with poor prognosis and is involved in epithelial ovarian cancer proliferation and invasion. European journal of cancer (Oxford, England : 1990). 2012; 48: 1914-21.

41. Zhang $\mathrm{P}$, Zhang P, Shi B, Zhou M, Jiang H, Zhang H, et al. Galectin-1 overexpression promotes progression and chemoresistance to cisplatin in epithelial ovarian cancer. Cell death \& disease. 2014; 5: e991.

42. Chen L, Yao Y, Sun L, Zhou J, Liu J, Wang J, et al. Clinical implication of the serum galectin-1 expression in epithelial ovarian cancer patients. Journal of ovarian research 2015; 8: 78 .

43. Schulz H, Schmoeckel E, Kuhn C, Hofmann S, Mayr D, Mahner S, et al. Galectins-1, -3, and -7 Are Prognostic Markers for Survival of Ovarian Cancer Patients. International journal of molecular sciences. 2017; 18.

44. Fukata M, Chen A, Vamadevan AS, Cohen J, Breglio K, Krishnareddy S, et al. Toll-like receptor-4 promotes the development of colitis-associated colorectal tumors. Gastroenterology. 2007; 133: 1869-81.

45. Park GB, Chung $\mathrm{YH}$, Kim D. Induction of galectin-1 by TLR-dependent PI3K activation enhances epithelial-mesenchymal transition of metastatic ovarian cancer cells. Oncology reports. 2017; 37: 3137-45.

46. Astorgues-Xerri L, Riveiro ME, Tijeras-Raballand A, Serova M, Rabinovich GA, Bieche I, et al. OTX008, a selective small-molecule inhibitor of galectin-1, downregulates cancer cell proliferation, invasion and tumour angiogenesis. European journal of cancer (Oxford, England : 1990). 2014; 50: 2463-77.

47. van den Brule FA, Buicu C, Berchuck A, Bast RC, Deprez M, Liu FT, et al. Expression of the $67-\mathrm{kD}$ laminin receptor, galectin-1, and galectin-3 in advanced human uterine adenocarcinoma. Human pathology. 1996; 27: $1185-91$

48. Mylonas I, Mayr D, Walzel H, Shabani N, Dian D, Kuhn C, et al. Mucin 1, Thomsen-Friedenreich expression and galectin-1 binding in endometrioid adenocarcinoma: an immunohistochemical analysis. Anticancer research. 2007; 27: 1975-80.

49. Lee JW, Song SY, Choi JJ, Choi CH, Kim TJ, Kim J, et al. Decreased galectin-3 expression during the progression of cervical neoplasia. Journal of cancer research and clinical oncology. 2006; 132: 241-7.

50. Li M, Feng YM, Fang SQ. Overexpression of ezrin and galectin-3 as predictors of poor prognosis of cervical cancer. Brazilian journal of medical and biological research $=$ Revista brasileira de pesquisas medicas e biologicas 2017; 50: e5356.

51. Liu J, Cheng Y, He M, Yao S. Vascular endothelial growth factor C enhances cervical cancer cell invasiveness via upregulation of galectin-3 protein. Gynecological endocrinology : the official journal of the International Society of Gynecological Endocrinology. 2014; 30: 461-5.

52. Stiasny A, Freier CP, Kuhn C, Schulze S, Mayr D, Alexiou C, et al. The involvement of E6, p53, p16, MDM2 and Gal-3 in the clinical outcome of patients with cervical cancer. Oncology letters. 2017; 14: 4467-76.

53. Fang SQ, Feng YM, Li M. Correlations of Galectin-3 Gene Polymorphisms with Risk and Prognosis of Cervical Cancer in Chinese Populations: A Case-Control Study. Oncology research and treatment. 2017; 40: 533-9.

54. Kim MK, Sung CO, Do IG, Jeon HK, Song TJ, Park HS, et al. Overexpression of Galectin-3 and its clinical significance in ovarian carcinoma. International journal of clinical oncology. 2011; 16: 352-8.

55. Lee JH, Zhang X, Shin BK, Lee ES, Kim I. Mac-2 binding protein and galectin-3 expression in mucinous tumours of the ovary: an annealing control primer system and immunohistochemical study. Pathology. 2009; 41: 229-33.

56. Mirandola L, Yu Y, Cannon MJ, Jenkins MR, Rahman RL, Nguyen DD, et al. Galectin-3 inhibition suppresses drug resistance, motility, invasion and angiogenic potential in ovarian cancer. Gynecologic oncology. 2014; 135: 573-9.

57. Brustmann $\mathrm{H}$. Epidermal growth factor receptor expression in serous ovarian carcinoma: an immunohistochemical study with galectin-3 and cyclin D1 and outcome. International journal of gynecological pathology : official journal of the International Society of Gynecological Pathologists. 2008; 27: 380-9.

58. Anastasi E, Gigli S, Santulli M, Tartaglione S, Ballesio L, Porpora MG, et al. Role of Galectin-3 Combined with Multi- Detector Contrast Enhanced Computed Tomography in Predicting Disease Recurrence in Patients with
Ovarian Cancer. Asian Pacific journal of cancer prevention : APJCP. 2017; 18: 1277-82

59. Oishi T, Itamochi H, Kigawa J, Kanamori Y, Shimada M, Takahashi M, et al. Galectin-3 may contribute to Cisplatin resistance in clear cell carcinoma of the ovary. International journal of gynecological cancer : official journal of the International Gynecological Cancer Society. 2007; 17: 1040-6.

60. Min KW, Park MH, Hong SR, Lee $\mathrm{H}$, Kwon SY, Hong SH, et al. Clear cell carcinomas of the ovary: a multi-institutional study of 129 cases in Korea with prognostic significance of Emi1 and Galectin-3. International journal of gynecological pathology : official journal of the International Society of Gynecological Pathologists. 2013; 32: 3-14

61. Lu H, Liu Y, Wang D, Wang L, Zhou H, Xu G, et al. Galectin-3 regulates metastatic capabilities and chemotherapy sensitivity in epithelial ovarian arinoma via NF-kappaB pathway. Tumour biology : the journal of the International Society for Oncodevelopmental Biology and Medicine. 2016; 37: 11469-77.

62. Kang HG, Kim DH, Kim SJ, Cho Y, Jung J, Jang W, et al. Galectin-3 supports stemness in ovarian cancer stem cells by activation of the Notch1 intracellular domain. Oncotarget. 2016; 7: 68229-41.

63. Hossein G, Keshavarz M, Ahmadi S, Naderi N. Synergistic effects of PectaSol-C modified citrus pectin an inhibitor of Galectin-3 and paclitaxel on apoptosis of human SKOV-3 ovarian cancer cells. Asian Pacific journal of cancer prevention : APJCP. 2013; 14: 7561-8.

64. Cai G, Ma X, Chen B, Huang Y, Liu S, Yang H, et al. Galectin-3 induces ovarian cancer cell survival and chemoresistance via TLR4 signaling activation. Tumour biology : the journal of the International Society for Oncodevelopmental Biology and Medicine. 2016; 37: 11883-91.

65. Al-Maghrabi J, Abdelrahman AS, Ghabrah T, Butt NS, Al-Maghrabi B, Khabaz MN. Immunohistochemical expression of galectin-3 is significantly associated with grade, stage and differentiation of endometrial carcinomas. Pathology, research and practice. 2017; 213: 348-52.

66. Ege $\mathrm{CB}$, Akbulut $\mathrm{M}$, Zekioglu $\mathrm{O}$, Ozdemir N. Investigation of galectin-3 and heparanase in endometrioid and serous carcinomas of the endometrium and correlation with known predictors of survival. Archives of gynecology and obstetrics. 2011; 284: 1231-9.

67. Stewart CJ, Crook ML. Galectin-3 expression in uterine endometrioid adenocarcinoma: comparison of staining in conventional tumor glands and in areas of MELF pattern myometrial invasion. International journal of gynecological pathology : official journal of the International Society of Gynecological Pathologists. 2010; 29: 555-61.

68. Brustmann H, Riss D, Naude S. Galectin-3 expression in normal, hyperplastic, and neoplastic endometrial tissues. Pathology, research and practice. 2003; 199: $151-8$

69. Lambropoulou M, Deftereou TE, Kynigopoulos S, Patsias A, Anagnostopoulos C, Alexiadis G, et al. Co-expression of galectin-3 and CRIP-1 in endometrial cancer: prognostic value and patient survival. Medical oncology (Northwood, London, England). 2016; 33: 8.

70. Cousins RJ, Lanningham-Foster L. Regulation of cysteine-rich intestinal protein, a zinc finger protein, by mediators of the immune response. The Journal of infectious diseases. 2000; 182 Suppl 1: S81-4.

71. Lei C, Zhang W, Sun X, Du G, Wang L, Liu Y. Effects of galectin-3 inhibition on endometrial cell cycle and adhesion. Frontiers of medicine in China. 2007; 1: 390-7.

72. Zhu H, Pei HP, Zeng S, Chen J, Shen LF, Zhong MZ, et al. Profiling protein markers associated with the sensitivity to concurrent chemoradiotherapy in human cervical carcinoma. Journal of proteome research. 2009; 8: 3969-76.

73. Zhu H, Wu TC, Chen WQ, Zhou LJ, Wu Y, Zeng L, et al. Roles of galectin-7 and S100A9 in cervical squamous carcinoma: Clinicopathological and in vitro evidence. International journal of cancer. 2013; 132: 1051-9.

74. Park JE, Chang WY, Cho M. Induction of matrix metalloproteinase-9 by galectin-7 through p38 MAPK signaling in HeLa human cervical epithelial adenocarcinoma cells. Oncology reports. 2009; 22: 1373-9.

75. Tsai CJ, Sulman EP, Eifel PJ, Jhingran A, Allen PK, Deavers MT, et al. Galectin-7 levels predict radiation response in squamous cell carcinoma of the cervix. Gynecologic oncology. 2013; 131: 645-9.

76. Higareda-Almaraz JC, Ruiz-Moreno JS, Klimentova J, Barbieri D, Salvador-Gallego R, Ly R, et al. Systems-level effects of ectopic galectin-7 reconstitution in cervical cancer and its microenvironment. BMC cancer. 2016; 16: 680

77. Kim HJ, Jeon HK, Lee JK, Sung CO, Do IG, Choi CH, et al. Clinical significance of galectin-7 in epithelial ovarian cancer. Anticancer research. 2013; 33: $1555-61$

78. Liang M, Ueno M, Oomizu S, Arikawa $\mathrm{T}$, Shinonaga $\mathrm{R}$, Zhang $\mathrm{S}$, et al. Galectin-9 expression links to malignant potential of cervical squamous cell carcinoma. Journal of cancer research and clinical oncology. 2008; 134: 899-907.

79. Schulz H, Kuhn C, Hofmann S, Mayr D, Mahner S, Jeschke U, et al. Overall Survival of Ovarian Cancer Patients Is Determined by Expression of Galectins-8 and -9. International journal of molecular sciences. 2018; 19:323.

80. Zucchetti M, Bonezzi K, Frapolli R, Sala F, Borsotti P, Zangarini M, et al. Pharmacokinetics and antineoplastic activity of galectin-1-targeting OTX008 in combination with sunitinib. Cancer chemotherapy and pharmacology. 2013; 72: 879-87. 